\title{
Reducing Enteric Methane Losses from Ruminant Livestock - Its Measurement, Prediction and the Influence of Diet
}

\author{
M. J. Bell and R. J. Eckard \\ Additional information is available at the end of the chapter
}

http://dx.doi.org/10.5772/50394

\section{Introduction}

Ruminant livestock systems contribute significantly to global anthropogenic methane emissions, with about $50 \%$ or more of the GHG emissions produced coming from enteric fermentation [1]. The loss of dietary energy in the form of methane has been extensively researched and reviewed [2, 3, 4]. Microorganisms called methanogens produce methane (methanogenesis) in the digestive tract as a by-product of anaerobic fermentation. Briefly, the process of methanogenesis [see 5, 6 for a more detailed summary] consists of:

1. Glucose equivalents from plant polymers or starch (cellulose, hemicellulose, pectin, starch, sucrose, fructans and pentosans) are hydrolysed by extracellular microbial enzymes to form pyruvate in the presence of protozoa and fungi in the digestive tract:

$$
\text { Glucose } \rightarrow 2 \text { pyruvate }+4 \mathrm{H}
$$

2. The fermentation of pyruvate involves oxidation reactions under anaerobic conditions producing reduced co-factors such as NADH. Reduced co-factors such as NADH are then re-oxidised to NAD to complete the synthesis of volatile fatty acids (VFAs) with the main products being acetate, butyrate and propionate (anions of acetic, butyric and propionic VFAs):

$$
\begin{gathered}
\text { Pyruvate }+\mathrm{H}_{2} \mathrm{O} \rightarrow \text { acetate }(\mathrm{C} 2)+\mathrm{CO}_{2}+2 \mathrm{H} \\
2 \mathrm{C} 2+4 \mathrm{H} \rightarrow \text { butyrate }(\mathrm{C} 4)+2 \mathrm{H}_{2} \mathrm{O} \\
\text { Pyruvate }+4 \mathrm{H} \rightarrow \text { propionate }(\mathrm{C} 3)+\mathrm{H}_{2} \mathrm{O}
\end{gathered}
$$

3. The VFAs are then available to be absorbed through the digestive mucosa into the animal's blood stream. The production of acetate and butyrate production provides a 
net source of hydrogen or alternatively propionate can utilise any available hydrogen Methanogens eliminate the available hydrogen by using carbon dioxide $\left(\mathrm{CO}_{2}\right)$ to produce methane:

$$
4 \mathrm{H}_{2}+\mathrm{CO}_{2} \rightarrow \mathrm{CH}_{4}+2 \mathrm{H}_{2} \mathrm{O}
$$

In ruminants, some 87 to $93 \%$ of methane production occurs in the foregut, with the highest rate of production being after eating [7]. In sheep, almost $90 \%$ of the methane produced in the hindgut has been found to be absorbed and expired through the lungs, with the remainder being excreted through the rectum [8]. Rectum enteric methane losses have been estimated at 7\% [9] and $8 \%$ [10] of methane output in dairy cows compared to the $1 \%$ found in sheep [8].

Reductions in enteric methane production from ruminants can result from a reduction in rumen fermentation rate (suppression in microbial activity) or a shift in VFA production [11]. An inverse relationship exists between the production of methane in the rumen and the presence of propionate. If the ratio of acetate to propionate was greater than 0.5 , then hydrogen would become available to form methane [12]. If the hydrogen produced is not correctly used by methanogens, such as when large amounts of fermentable carbohydrate are fed, ethanol or lactate can form, which inhibits microbial growth, forage digestion, and any further production of VFAs [13]. In practice, ethanol or lactate may form, but any excess hydrogen is simply eructated.

The methods for sampling, measuring and predicting enteric methane production (using studies on dairy cattle as an example), and the influence of dietary components on methane production are reviewed.

\section{Methods used to sample and measure methane production}

Estimates of methane output from livestock can be costly and difficult to make, especially from larger ruminants. Standard methods for measuring the methane concentration in air are by infrared spectroscopy, gas chromatography, mass spectroscopy or a tuneable laser diode. In a controlled and enclosed environment (i.e. chamber) the gas concentration can be calculated directly from the difference between ingoing and outgoing air, but in less contained environments a tracer gas is required as a marker, which is often the inert sulphur hexafluoride $\left(\mathrm{SF}_{6}\right)$ gas.

Of the methods summarised [from the reviews of 7,12] in Table 1 that can be used to sample air for its methane concentration, the open-circuit indirect respiration calorimeter (chamber) is acknowledged as currently providing the most reliable and repeatable method of obtaining an estimate of individual whole animal enteric methane emissions (including eructated and flatulence emissions) over a continuous sampling period [7]. If this method becomes less costly to implement, direct selection of animals on methane output could become possible. In some cases, there are suggestions that this technique may affect the 
behaviour of the animal causing depression of appetite [14, 15], which may be avoided by making the walls of the enclosed environment transparent. A more mobile chamber that has been used is a polythene tunnel. Due to the polythene tunnel being mobile it is adaptable to different feeding systems such as grazing animals [14, 16]. However, difficulties in controlling the tunnel's temperature and humidity have been found, resulting in a lower estimate of methane production compared to chamber measurements [14, 16].

Method of measurement Description

\section{Whole animal emissions measured}

Chamber

Open-circuit indirect respiration calorimeter. Air blown in and extracted out of a chamber. Air concentrations between the incoming and outgoing air are continuously monitored using gas analysers. Chamber conditions are controlled and monitored usually for 48 hours.

Polythene tunnel $\begin{aligned} & \text { Air blown in and extracted out of tunnel. Air concentrations } \\ & \text { between the incoming and outgoing air are continuously } \\ & \text { monitored. }\end{aligned}$

Room tracer gas Tracer gas is released into a ventilated room until a steady concentration is reached, after which air samples can be collected. Background air samples are required.

Mass balance Background air samples and a high precision gas analyser are micrometerological required. Sampling downwind (and up) of the source.

\section{Eructated emissions measured}

Head box, hood or mask Respired gas volume can be sampled at regular intervals.

ERUCT (Emissions from Typically using the inert sulphur hexafluoride $\left(\mathrm{SF}_{6}\right)$ tracer gas. ruminants using a Assumes that the emitted tracer gas from a permeation tube in the calibrated tracer) rumen simulates the diffusion of any methane emitted. Respired air collected via a capillary tube near the animal's nostrils into a vessel.

Table 1. A general summary of a few methods used to collect air samples to measure whole animal enteric methane emissions or solely eructated emissions

In comparison to methods that use a controlled and enclosed environment, methods that use a tracer gas such as $\mathrm{SF}_{6}$ as a marker tend to be less costly and more applicable to use on a greater number of animals. The room tracer [17] and mass balance micrometerological methods, where a known amount of gas i.e. a tracer gas or the gas of interest are released from fixed points $[18,19,20]$, both require careful monitoring of the sampling environment and diffusion of the gas of interest (in this case methane) needs to be tested prior to 
commencing sampling. The temperature, air pressure, humidity and air speed should also be monitored for their consistency in a non-enclosed sampling environment. Controlling the sampling environment would make replicating these techniques consistently on commercial farms difficult. Also, in some countries the use of $\mathrm{SF}_{6}$ is not permitted and there may be a withdrawal period on products from animals exposed to the gas [7]. The ERUCT (emissions from ruminants using a calibrated tracer) technique $[9,21]$ or a head box, hood or mask $[22,23]$ estimate eructated methane emissions from individual animals. This ignores enteric methane from the rectum, which could be 1 to $8 \%$ of total enteric methane production of an animal as previously discussed. The ERUCT technique was devised to allow measurement of methane emissions from free ranging and feedlot animals. The ERUCT technique has been found to be suitable for estimating respired methane emissions from high forage fed animals and not with animals on diets that result in greater post-ruminal digestion [21,24]. Even though the ERUCT technique is more open to errors in estimates compared to using a chamber, these errors could be reduced by removal of outlying estimates and replicating sampling over several days [10]. More invasive methods of estimating methane production from rumen fluid involve injecting radioactively labelled methane (isotope dilution technique) [8, 25] or ethane [26] into the rumen.

\section{Methane output measurements}

Studies measuring the methane production of livestock have been carried out for over 80 years (Table 2). In the last 20 years the number of studies globally that have measured enteric methane have increased, as have the range of sampling methods used.

In cattle, the use of high energy dense diets has increased the amount of dry matter (DM) that an animal can consume, as a result of improved efficiencies in rumen fermentation and feed digestibility [42]. The level of intake of feed (more specifically organic matter) influences methane production. Dairy cows ranging in live weight from 385 to $747 \mathrm{~kg}$ were found to produce between 45 and $199 \mathrm{~kg}$ methane/head/yr (14 to $31 \mathrm{~g} / \mathrm{kg}$ DM intake) of methane and beef cattle of 364 to $627 \mathrm{~kg}$ live weight produced between 40 and $92 \mathrm{~kg}$ methane/head/yr (13 to $35 \mathrm{~g} / \mathrm{kg}$ DM intake), with the difference attributed to the amount of DM consumed [43]. Notably in Table 2 the highest DM intake measured was $29 \mathrm{~kg} / \mathrm{day}$ in two of the studies $[33,41]$ and the methane production was also the same at $19 \mathrm{~g} / \mathrm{kg} \mathrm{DM}$ intake. Where a high energy dense diet is formulated to meet the nutrient requirements of a high milk yielding animal, it would appear that the methane output per $\mathrm{kg}$ DM intake could average about $19 \mathrm{~g} / \mathrm{kg}$, but this would be slightly more for high forage diets where potential intake is lower $(0.21 \mathrm{~g} / \mathrm{kg}$ DM or more [44]). As well as the influence of the composition of the diet, reductions in methane losses per $\mathrm{kg}$ DM intake appear to be possible by an incremental increase in the level of feed intake, brought about by increasing the proportion of concentrate feed in the diet. It has been suggested that this decrease in the percentage of dietary GE intake lost as methane occurs at an average of $1.6 \%$ per unit increase in feed level [12]. 


\begin{tabular}{|c|c|c|c|c|}
\hline Reference & $\begin{array}{l}\text { Dry matter intake } \\
(\mathrm{kg} / \text { day })\end{array}$ & $\begin{array}{l}\text { Body weight } \\
(\mathrm{kg})\end{array}$ & $\begin{array}{l}\text { Methane } \\
(\mathrm{kg} / \mathrm{hd} / \mathrm{yr})\end{array}$ & Sampling method \\
\hline [10] & 18 & 496 & 120 & ERUCT / Chamber \\
\hline [17] & 25 & - & 102 & Room tracer $\left(\mathrm{SF}_{6}\right)$ \\
\hline [18] & - & 600 & 142 & $\begin{array}{l}\text { Micrometeorological mass } \\
\text { balance }\end{array}$ \\
\hline [27] & $1-15$ & $162-655$ & 39 & Chamber \\
\hline [28] & 9 & - & 79 & Chamber \\
\hline [29] & - & - & 40 & Chamber \\
\hline [30] & $8-18$ & - & $68-122$ & Chamber \\
\hline [31] & 18 & 602 & 137 & $\begin{array}{l}\text { Micrometeorological mass } \\
\text { balance }\end{array}$ \\
\hline [32] & - & $450-700$ & 112 & Chamber \\
\hline [33] & $4-29$ & $426-852$ & $24-198$ & Chamber \\
\hline [34] & 13 & $402-562$ & 96 & ERUCT \\
\hline [35] & 13 & 517 & 95 & Chamber \\
\hline [36] & $14-16$ & 595 & 138 & Chamber \\
\hline [37] & 14 & - & 109 & ERUCT \\
\hline [38] & 12 & 526 & 84 & $\begin{array}{l}\text { Chamber / mask / ERUCT / } \\
\text { micrometeorological mass } \\
\text { balance }\end{array}$ \\
\hline [39] & 20 & 572 & 137 & Chamber \\
\hline [40] & $8-25$ & $379-733$ & $72-210$ & Chamber \\
\hline [41] & $2-29$ & $173-826$ & $13-197$ & Chamber \\
\hline
\end{tabular}

* Most recent reference to data collected is shown and values where available are presented.

Table 2. Some of the key experiments globally that have measured methane output from dairy cattle*

\section{Methane output prediction equations}

Prediction methods can be either empirical or mechanistic. Several reviews have studied the use and performance of different methane output prediction equations $[11,12,33,38,45,46$, $47,48,49]$.

Mechanistic equations estimate methane output using mathematical descriptions of rumen fermentation. Even though mechanistic equations at present appear to show the greatest degree of adaptability across diet types and intake level [48, 50,51], they require detailed and complex dietary input values. Published mechanistic equations are not presented in this review but are described in [52] (recommended in [50] and [46]), [53], [54], [55], [56], [57], [58], [59] (recommended in [50]) and [60].

Empirical equations such as those shown in Table 3 offer a more practical solution to predicting methane output using input variables such as digestibility, carbohydrate content, energy and nitrogen intake, milk production and live weight. Table 3 and Figure 1 present 
empirical prediction equations for methane output developed using animals that included dairy cattle, with a range of intakes and different diets. Of the empirical prediction equations shown in Table 3, studies have compared the predictions of an equation against methane measurements, with some being recommended such as [29] (recommended in [33]), [61] (recommended in [33], [12], [46] and [47]), [62] (recommended in [63]) and the non-linear equations using DM intake and metabolisable energy (ME) intake by [47] (recommended in [48] and [38]).

\begin{tabular}{|c|c|c|}
\hline Reference & Units & Equation \\
\hline [27] & g/day & $=18+22.5 \times \mathrm{DMI}$ \\
\hline [28] & MJ/day & $=-2.07+2.63 \times \mathrm{DMI}-0.105 \times \mathrm{DMI}^{2}$ \\
\hline [29] & MJ/day & $=[1.3+0.112 \times \mathrm{D}+\mathrm{FL} \times(2.37-0.05 \times \mathrm{D}) / 100] \times \mathrm{GEI}$ \\
\hline [32] & g/day & $=10.0+4.9 \times \mathrm{MY}+1.5 \times \mathrm{LWGT}^{0.75}$ \\
\hline \multirow[t]{4}{*}{ [37] } & g/day & $=17.1 \times \mathrm{DMI}+97.4$ \\
\hline & g/day & $=84+47 \times C+32 \times S+62 \times D S$ \\
\hline & g/day & $=91+50 \times \mathrm{C}+40 \times \mathrm{HC}+24 \times \mathrm{S}+67 \times \mathrm{DS}$ \\
\hline & g/day & $=123+84 \times \mathrm{C}-30 \times \mathrm{HC}+58 \times \mathrm{S}+73 \times \mathrm{DS}-95 \times \mathrm{L}$ \\
\hline \multirow[t]{2}{*}{ [38] } & MJ/day & $=8.56+0.14 \times \mathrm{FP}$ \\
\hline & MJ/day & $=3.23+0.81 \times \mathrm{DMI}$ \\
\hline \multirow[t]{4}{*}{ [41] } & MJ/day & $=74.43-(74.43+0) \times \mathrm{e}^{[-0.0163 \times \mathrm{DMI}]}$ \\
\hline & MJ/day & $\begin{array}{l}=74.43-(74.43+0) \times \mathrm{e}[\mathrm{cx}] ; \mathrm{cx}=-0.0187+0.0059 /[1+\exp (\mathrm{S} / \mathrm{TADF}- \\
3.1003)] / 0.6127 \times \mathrm{DMI}\end{array}$ \\
\hline & MJ/day & $=(7.16-0.101 \times \mathrm{DMI}) / 100 \times \mathrm{GEI}$ \\
\hline & MJ/day & $=2.6861+0.0779 \times$ DEI \\
\hline \multirow[t]{7}{*}{ [47] } & MJ/day & $=5.93+0.92 \times \mathrm{DMI}$ \\
\hline & MJ/day & $=8.25+0.07 \times \mathrm{MEI}$ \\
\hline & MJ/day & $=7.30+13.13 \times \mathrm{N}+2.04 \mathrm{TADF}+0.33 \times \mathrm{S}$ \\
\hline & MJ/day & $=1.06+10.27 \times \mathrm{FP}+0.87 \times \mathrm{DMI}$ \\
\hline & MJ/day & $=56.27-(56.27+0) \times \mathrm{e}^{[-0.028 \times \mathrm{DMI}]}$ \\
\hline & MJ/day & $=45.89-(45.89+0) \times \mathrm{e}^{[-0.003 \times \mathrm{MEI}]}$ \\
\hline & MJ/day & $=45.98-(45.98+0) \times \mathrm{e}^{[\mathrm{cx}]} ; \mathrm{cx}=-0.0011 \times(\mathrm{S} / \mathrm{TADF})+0.0045 \times \mathrm{MEI}$ \\
\hline [61] & MJ/day & $=3.38+0.51 \times \mathrm{NFC}+1.74 \times \mathrm{HC}+2.652 \times \mathrm{C}$ \\
\hline \multirow[t]{2}{*}{ [62] } & MJ/day & $=\mathrm{DEI} \times[0.094+0.028 \times(\mathrm{FADF} / \mathrm{TADF})]-2.453 \times(\mathrm{FL}-1)$ \\
\hline & MJ/day & $=\mathrm{DEI} \times[0.096+0.035 \times(\mathrm{FDMI} / \mathrm{DMI})]-2.298 \times(\mathrm{FL}-1)$ \\
\hline [64] & g/day & $=4.012 \times \mathrm{TC}+17.68$ \\
\hline \multirow[t]{3}{*}{ [65] } & $\%$ GEI & $\begin{array}{l}=2.898-0.0631 \times \mathrm{MY}+0.297 \times \mathrm{MF}-1.587 \times \mathrm{MP}+0.0891 \times \mathrm{CP}+ \\
0.1010 \times[(\mathrm{FADF} / \mathrm{DMI}) \times 100]+0.102 \times \mathrm{DMI}-0.131 \times \mathrm{F}+0.116 \times \\
\mathrm{DMD}-0.0737 \times \mathrm{CPD}\end{array}$ \\
\hline & $\%$ GEI & $\begin{array}{l}=2.927-0.0405 \times \mathrm{MY}+0.335 \times \mathrm{MF}-1.225 \times \mathrm{MP}+0.248 \times \mathrm{CP}-0.448 \\
\times[(\mathrm{ADF} / \mathrm{DMI}) \times 100]+0.502 \times[(\mathrm{FADF} / \mathrm{DMI}) \times 100)+0.0352 \times \\
\mathrm{ADFD}\end{array}$ \\
\hline & $\%$ GEI & $\begin{array}{l}=227.099-2.783 \times[(\mathrm{ADFD} / \mathrm{DMI}) \times 100]-6.0176 \times \mathrm{ADFD}+3.607 \times \\
\mathrm{CPD}+1.751 \times \mathrm{NDSD}-1.423 \times \mathrm{CD}+1.203 \times \mathrm{HD}\end{array}$ \\
\hline
\end{tabular}




\begin{tabular}{lll}
\hline Reference & Units & Equation \\
\hline$[66]$ & g/day & $=41+30 \times \mathrm{DS}+6 \times \mathrm{S}+51 \times \mathrm{DCW}$ \\
\hline$[67]$ & MJ/day & $=1.36+1.21 \times \mathrm{DMI}-0.825 \times \mathrm{CDMI}+12.8 \times \mathrm{NDF}$ \\
\hline$[68]$ & L/day & $=38.92+26.44 \times \mathrm{DMI}$ \\
\hline$[69]$ & L/day & $=47.82 \times \mathrm{DMI}-0.762 \times \mathrm{DMI}^{2}-41$ \\
\hline$[70]$ & L/day & $=38.2+4.89 \times \mathrm{FP} \times \mathrm{DMI}-0.719 \times \mathrm{DMI}^{2}-20$ \\
& L/day & $=0.666 \times \mathrm{LWGT}+2.868 \times \mathrm{MY}+75$ \\
& L/day & $=39.2 \times \mathrm{DMI}-0.588 \times \mathrm{DMI}^{2}+0.370 \times \mathrm{LWGT}-1.698 \times \mathrm{MY}-134$ \\
\hline
\end{tabular}

$\mathrm{DMI}=$ dry matter intake $(\mathrm{kg} /$ day $) ; \mathrm{CDMI}=$ concentrate DMI $(\mathrm{kg} /$ day $) ; \mathrm{FDMI}=$ forage DMI (kg/day); TC = total NDF, sugar and starch (100 g/day); D = digestibility of gross energy at maintenance (\%); NFC = non-fibre carbohydrate (kg/day); $\mathrm{HC}=$ hemicellulose $(\mathrm{kg} /$ day); $\mathrm{C}=$ cellulose $(\mathrm{kg} /$ day $) ; \mathrm{MY}=$ milk yield $(\mathrm{kg} /$ day); $\mathrm{MF}=$ milk fat composition $(\%) ; \mathrm{MP}=$ milk protein composition (\%); $\mathrm{CP}=$ crude protein $(\% \mathrm{DMI}) ; \mathrm{F}=$ fat $(\% \mathrm{DMI}) ; \mathrm{DMD}=\mathrm{DM}$ digestibility $(\%)$; $\mathrm{CPD}=\mathrm{CP}$ digestibility (\%); $\mathrm{ADFD}=$ acid detergent fibre digestibility $(\%) ; \mathrm{NDSD}=$ neutral detergent solubles digestibility (\%); $\mathrm{CD}=$ cellulose digestibility (\%); $\mathrm{HD}=$ hemicellulose digestibility (\%); $\mathrm{DS}=$ sugars (kg/day); DCW = digested cell walls (kg/day); L = lignin (kg/day); LWGT = live weight (kg); DEI = digestible energy intake $(\mathrm{MJ} /$ day); $\mathrm{MEI}=$ metabolisable energy intake $(\mathrm{MJ} /$ day $) ; \mathrm{GEI}$ = gross energy intake $(\mathrm{MJ} /$ day $) ; \mathrm{FADF}=$ forage ADF $(\mathrm{kg} / \mathrm{day}) ; \mathrm{TADF}$ $=$ total $\mathrm{ADF}(\mathrm{kg} /$ day $) ; \mathrm{FL}=$ multiples of MEI over maintenance; $\mathrm{NDF}=$ neutral detergent fibre $(\mathrm{kg} / \mathrm{kg} \mathrm{DM}) ; \mathrm{FP}=$ forage proportion ( $\mathrm{kg} / \mathrm{kg} \mathrm{DM}) ; \mathrm{N}$ = nitrogen (kg/day); $\mathrm{S}=\operatorname{starch}(\mathrm{kg} /$ day).

Table 3. Empirical equations from the literature that predict enteric methane output from dietary inputs and production values for dairy cattle

The success or suitability of an empirical prediction equation for implementation on a data set is dependent on the range of values that the equation was developed on. A comparison of empirical prediction equations from Table 3, which were tested over a range of DM intakes from 1 to $35 \mathrm{~kg} / \mathrm{d}$ (beyond the range they would have been developed on) for lactating dairy cows fed diets with a high and low proportion of forage content, suggest that the relationship between methane output and intake may be linear up to an average intake of $15 \mathrm{~kg} \mathrm{DM} / \mathrm{d}$. Above this level of intake, which is more achievable by feeding a higher proportion of concentrates in the diet, the majority of equations showed a decline in methane output per unit intake (due to the increase in the level of intake by feeding a higher proportion of concentrate feed as has been suggested [12]; Fig. 1). This depression in methane lost per $\mathrm{kg}$ DM intake at high levels of intake in cattle has also been shown in other studies (reported in [71]). The main difference amongst the performances of methane prediction equations is their ability to give a sensible estimate of methane losses at low (approaching the origin) and high dry matter intakes. Even though some of the variation in the predictive ability of an equation in Figure 1 may be explained by the equation being used on a range of values outside the range it was developed on and the complexity of an equation, there is still considerable variation in methane output for a given level of DM intake [71].

In addition to dynamic and statistical prediction methods, methane output can be estimated based on an animal's predicted energy requirements, which is the technique used in the Intergovernmental Panel on Climate Change (IPCC) methodology [72, 73]. This energy balance approach is suitable as an estimate over a period of time (as used in national inventories based on IPCC methodology) such as a year or lactation [74]. The IPCC methodology is based on production variables that are generally more easily obtained than those used in empirical or even more dynamic enteric methane prediction equations. 


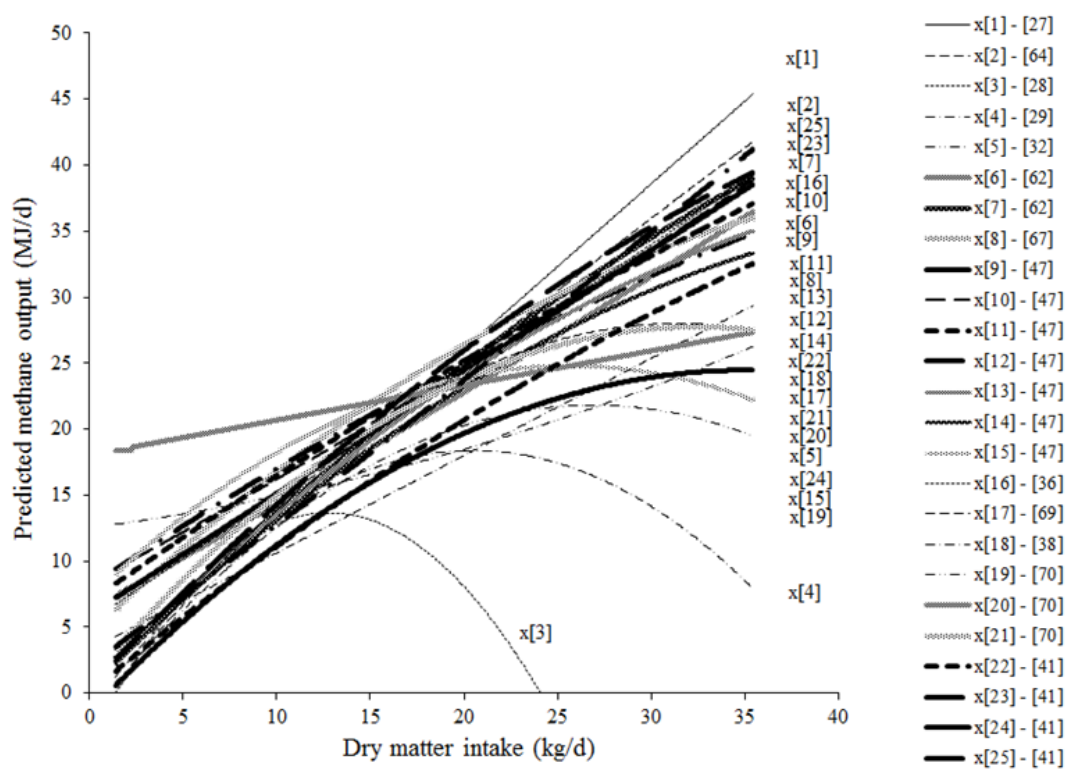

Figure 1. Average methane output polynomial trend lines for methane output predictions by published equations (in Table 3) $x[1]$ to $x[25]$ across a range of daily dry matter intakes of dairy cows (from [49])

\section{Effect of diet on methane output}

As suggested in Figure 1 and proposed by others [29], increased intake of less digestible feeds such as forage has little effect on methane production per DM intake, whereas an increase in more digestible feeds such as concentrate results in a reduction in methane losses per DM intake. This improvement in the quality of food fed to a ruminant is an effective way to manipulate the diet (particularly in terms of digestible organic matter) to get better animal performance and reduced methane production [40, 45, 70, 75].

Individual feeds can vary considerably in their methanogenic effect based on their chemical composition. An evaluation of chamber measurements of methane from sheep fed different feeds found a range for percentage of GE lost as methane from $3.8 \%$ for distillers grains to $12.8 \%$ for peas [76]. The authors found that $92 \%$ of the variation in methane emission was explained by the equation:

Methane output $(\% \mathrm{GE})=-10.5+0.192 \times \mathrm{DE}-0.0567 \times \mathrm{EE}+0.00651 \times \mathrm{S}+0.00647 \times \mathrm{CP}+$ $0.0111 \times \mathrm{NDF}$

where, $\mathrm{DE}$ is digestible energy (\% of gross energy, GE), $\mathrm{EE}$ is ether extract, $\mathrm{S}$ is starch, $\mathrm{CP}$ is crude protein and NDF is neutral detergent fibre (all in $\mathrm{g} / \mathrm{kg} \mathrm{DM}$ ).

The above equation shows the relative response in methane output to each dietary component, with increases in DE, S, CP increasing methane emissions and increasing EE reducing methane. These parameters and their positive or negative effect on methane are 
common inputs to equations in Table 3. However, this would suggest that high starch feeds such as cereal grain would increase methane emissions. But when fed at an increasing level of intake cereal grains have a curvilinear effect on fibre digestion in mixed rations ([71]; expressed as a ratio of starch to acid detergent fibre content in [41, 47]) and result in a depression in methane per unit DM (as in Fig.1 in [47]) and per unit product.

Diet composition can influence rumen fermentation and reduce methane production as a result of more propionate present or less degradation of food consumed in the rumen. Postruminal digestion, particularly in the small intestine, is energetically more efficient with lower methane losses than digestion in the rumen, which can be encouraged by more digestible and higher quality food. The amount and type of dietary carbohydrate fermented affects the fermentation rate and rumen retention time of substrate, in addition to the hydrogen supply due to the ratio of acetate to propionate. The passage rate of substrate and rumen fluid dilution rate (influencing the ratio of acetate to propionate) have been found to explain $28 \%$ and $25 \%$ of variation in an animal's methane production [77]. Cellulose ferments more slowly than hemicellulose, but both these structural carbohydrates ferment more slowly than non-structural and more soluble carbohydrates such as starch and sugars [2]. With regard to forages, increasing the digestibility of forage fed by reducing fibre content can reduce methane production. Feeding maize silage [78] or a legume-based silage [45] rather than grass silage has been found to reduce methane production. Also, silage is generally more digestible than hay [45] and adding molasses or urea to straw made it more digestible [79], which in both cases reduced methane production. Forage methane production can be minimised by lower fibre content and high soluble carbohydrate (influenced by maturity), and C3 grasses rather than C4 [2]. The grinding or pelleting of forage to increase its surface area and digestibility could also help reduce methane production $[12,80]$.

The additions of feed additives to a ruminant's diet have been and are still being extensively evaluated for their effect on reducing methane emissions. The benefit in animal productivity and reduction in methane production relative to the cost of using different additives is continually being assessed. As previously suggested, the supplementation of diets with additives such as fats can reduce methane production $[12,44,65,81,82,83,84]$ particularly fats with C8 to C16 chain length such as coconut oil [56, 85], however the effect, which is a suppression on fermentation appears to not always last [17, 37]. Suppressing fermentation by supplementing the diet with fat inhibits methanogens and protozoa, and subsequent fibre digestion with a shift towards more propionate present rather than acetate [2]. Likewise, the use of ionophores in feed (particularly monensin and salinomycin) and spices [86] that modify the rumen microflora [87] can reduce methane losses [6, 7, 88, 89] and encourage a shift towards propionogenesis. However eventually the rumen microflora would appear to show some resistance and the suppression ceases [90, 91, 92]. The inconsistent effects of monensin on methane in dairy cattle on forage and grain supplemented diets have also been found [93,94]. Notably, ionophores are banned within the European Union due to the fears of residues appearing in the milk.

Other feed additives tested include the use of plant compounds such as tannins (inhibiting methanogens) [95] and saponins (inhibiting protozoa), which reduce the digestibility of 
dietary fibre [96], and organic acids such as fumarate, malate and acrylate which act as an alternative hydrogen acceptor [97], but results for effects on methane production and animal performance are variable [3]. Probiotics (acetogens and yeast) have been found to reduce methane output, mainly through improving digestion efficiency [88] but not by others [3]. Overall, unless yeast by-products can reliably be used to reduce methane production, the most cost-effective additive for reducing production appears to be the addition of cellulase and hemicellulase enzymes to a ruminant's diet, which not only improved fibre digestion but also productivity [98].

\section{Conclusions}

With the increased importance now attached to enteric methane emissions from ruminants, due its global warming potential, there has been and will continue to be improvements in our understanding of methanogenesis and abatement options. Chamber measurements are costly in comparison to other measurement techniques and prediction methods, and therefore methane predictions using mechanistic models describing rumen fermentation are recognised at present as being more applicable to different feeds and animal species. The methane output from different feeds and animals has been extensively measured, predicted and tested but a robust empirical prediction of enteric methane emissions that can be applied to any ruminant production system is still to be developed. This is partly due to the need for the effect of feeding level to be better defined.

The important variables for predicting enteric methane output are the contents of fermentable carbohydrate, fibre, fat, digestible energy and intake level of a diet. Low enteric methane losses per unit DM appear possible by mechanisms that promote the passage of organic matter to post-rumen digestion and reduce rumen fermentation by high intakes of digestible feed and addition of fats, whilst also reducing emissions per unit product.

\section{Author details}

M. J. Bell*

Melbourne School of Land and Environment, University of Melbourne, Vic. 3010, Australia

R. J. Eckard

Primary Industries Climate Challenges Centre, The University of Melbourne E Department of Primary Industries, Australia

\section{Acknowledgement}

This work was supported by funding from Dairy Australia, Meat and Livestock Australia and the Australian Government Department of Agriculture, Fisheries and Forestry under its Australia's Farming Future Climate Change Research Program.

${ }^{*}$ Corresponding Author 


\section{References}

[1] Steinfeld H, Gerber P, Wassenaar T, Castel V, Rosales M, de Haan C (2006) Livestock's long shadow - Environmental issues and options. FAO report, Rome, Italy.

[2] Eckard R.J, Grainger C, de Klein C.A.M. (2010) Options for the abatement of methane and nitrous oxide from ruminant production: A review. Livest. Sci. 130:47-56.

[3] Martin C, Morgavi D.P, Doreau M (2010) Methane mitigation in ruminants: from microbe to the farm scale. Animal 4:351-365.

[4] Cottle D.J, Nolan J.V, Wiedemann SG (2011) Ruminant enteric methane mitigation: a review. Anim. Prod. Sci. 51:491-514.

[5] McDonald P, Edwards R.A, Greenhalgh J.F.D, Morgan C.A (1995) Animal Nutrition. Fifth Edition. Longman press, Harlow, UK.

[6] Moss A.R, Jouany J-P, Newbold J (2000) Methane production by ruminants: its contribution to global warming. Ann. Zootech. 49:231-253.

[7] Kebreab E, Clark K, Wagner-Riddle C, France J (2006a) Methane and nitrous oxide emissions from Canadian animal agriculture: A review. Can. J. Anim. Sci. 86:135-158.

[8] Murray R.M, Bryant A.M, Leng R.A (1976) Rates of production of methane in the rumen and large intestines of sheep. Br. J. Nutr. 36:1-14.

[9] Grainger C, Clarke T, McGinn S.M, Auldist M.J, Beauchemin K.A, Hannah M.C, Waghorn G.C, Clark H, Eckard R.J (2007) Methane emissions from dairy cows measured using the sulphur hexafluoride $\left(\mathrm{SF}_{6}\right)$ tracer and chamber techniques. J. Dairy Sci. 90:2755-2766.

[10] Tamminga S, Bannink A, Dijkstra J, Zom R (2007) Feeding strategies to reduce methane loss in cattle. Animal Science Group report, Wageningen, The Netherlands.

[11] Johnson K.A, Johnson D.E (1995) Methane emissions from cattle. J. Anim. Sci. 73:2483-2492.

[12] Joblin K.N (1999) Ruminal acetogens and their potential to lower ruminant methane emissions. Aust. J. Agric. Res. 50:1307-1313.

[13] Murray P.J, Moss A, Lockyer D.R, Jarvis S.C (1999) A comparison of systems for measuring methane emissions from sheep. J. Agric. Sci. 133:439-444.

[14] Sherlock J (2005) Defra research in agriculture and environmental protection between 1990 and 2005: summary and analysis report (ES0127). Final report to Defra. Defra, London, UK.

[15] Lockyer D.R, Jarvis S.C (1995) The measurement of methane losses from grazing animals. Environ. Pollut. 90:383-390.

[16] Johnson K.A, Kincaid R.L, Westberg H.H, Gaskins C.T, Lamb B.K, Cronrath J.D (2002) The effect of oilseeds in diets of lactating cows on milk production and methane emissions. J. Dairy Sci. 85:1509-1515.

[17] Kaharabata S.K, Schuepp P.H, Desjardins R (2000) Estimating methane emissions from dairy cattle housed in a barn and feedlot using an atmospheric tracer. Environ. Sci. Technol. 34:3296-3302.

[18] Laubach J, Kelliher F (2005) Methane emissions from dairy cows: Comparing open-path laser measurements to profile-based techniques. Agricult. Forest Meteorol. 135:340-345.

[19] Griffith D.W.T, Glenn R, Bryant D.H, Reisinger A.R (2008) Methane emissions from free-ranging cattle: comparison of tracer and integrated horizontal flux techniques. J. Environ. Qual. 37:582-591. 
[20] Vlaming J.B, Clark H, Lopez-Villalobos N (2005) The effect of SF6 release rate, animal species and feeding conditions on estimates of methane emissions from ruminants. In: Proceedings of the New Zealand Society for Animal Production, 65:4-8.

[21] Belyea R.L, Marin P.J, Sedgwick H.T (1985) Utilization of chopped and long alfalfa by dairy heifers. J. Dairy Sci. 68:1297-1301.

[22] Kelly J.M, Kerrigan B, Milligan L.P, McBride B.W (1994) Development of a mobile, open circuit indirect calorimetry system. Can. J. Anim. Sci. 74:65-72.

[23] McGinn S.M, Beauchemin K.A, Iwaasa A.D, McAllister T.A (2006) Assessment of the sulfur hexafluoride $\left(\mathrm{SF}_{6}\right)$ tracer technique for measuring enteric methane emissions from cattle. J. Environ. Qual. 35:1686-1691.

[24] France J, Beever D.E, Siddons R.C (1993) Compartmental schemes for estimating methanogenesis in ruminants from isotope dilution data. J. Theor. Biol. 164:207-218.

[25] Moate P.J, Clarke T, Davies L.H, Laby R.H (1997) Rumen gases and load in grazing dairy cows. J. Agric. Sci. 129:459-469.

[26] Kriss M (1930) Quantitative relations of the dry matter of the food consumed, the heat production, the gaseous outgo, and the insensible loss in body weight of cattle. J. Agric. Res. 40:283-295.

[27] Axelsson J (1949) The amount of produced methane energy in the European metabolic experiments with adult cattle. Annals of the Royal Agricultural College of Sweden, 16:404-419.

[28] Blaxter K.L, Clapperton J.L (1965) Prediction of the amount of methane produced by ruminants. Brit. J. Nutr. 19:511-522.

[29] Shibata M, Terada F, Kurihara M, Nishida T, Iwasaki K (1993) Estimation of methane production in ruminants. Anim. Sci. Technol. 64:790-796.

[30] Kinsman R, Sauer F.D, Jackson H.A, Wolynetz M.S (1995) Methane and carbon dioxide emissions from dairy cows in full lactation monitored over a six-month period. J. Dairy Sci. 78:2760-2766.

[31] Kirchgessner M, Windisch W, Muller H.L (1995) Nutritional factors for the quantification of methane production. In: Proceedings 8th International Symposium on Ruminant Physiology, Ruminant Physiology: Digestion, Metabolism Growth and Reproduction, Stuttgart, Germany, pp. 333-348.

[32] Wilkerson V.A, Casper D.P, Mertens D.R (1995) The Prediction of methane production of Holstein cows by several equations. J. Dairy Sci. 78:2402-2414.

[33] Ulyatt M.J, Lassey K.R, Martin R.J, Walker C.F, Shelton I.D (1997) Methane emission from grazing sheep and cattle. In: Proceedings of the New Zealand Society of Animal Production, 57:130-133.

[34] Bruinenberg M.H, van Der Honing Y, Agnew R.E, Yan T, van Vuuren A.M, Valk H (2002) Energy metabolism of dairy cows fed on grass. Livest. Prod. Sci. 75:117-128.

[35] Hindrichsen I.K, Wettstein H-R, Machmuller A, Jorg B, Kreuzer M (2005) Effect of the carbohydrate composition of feed concentratates on methane emission from dairy cows and their slurry. Environ.1 Monit. Assess. 107:329-350.

[36] Woodward S.L, Waghorn G.C, Thomson N.A (2006) Supplementing dairy cows with oils to improve performance and reduce methane-Does it work? In: Proceedings of the New Zealand Society of Animal Production, 66:176-181. 
[37] Ellis J.L, Kebreab E, Odongo N.E, McBride B.W, Okine E.K, France J (2007) Prediction of methane production from dairy and beef cattle. J. Dairy Sci. 90:3456-3467.

[38] van Knegsel A.T.M, van den Brand H, Dijkstra J, van Straalen W.M, Heetkamp M.J.W, Tamminga S, Kemp B (2007) Dietary energy source in dairy cows in early lactation: energy partitioning and milk composition. J. Dairy Sci. 90:1467-1476.

[39] Yan T, Mayne C.S, Gordon F.G, Porter M.G, Agnew R.E, Patterson D.C, Ferris C.P, Kilpatrick D.J (2010) Mitigation of enteric methane emissions through improving efficiency of energy utilization and productivity in lactating dairy cows. J. Dairy Sci. 93:2630-2638.

[40] Mills J.A.N, Crompton L.A, Bannink A, Tamminga S, Moorby J, Reynolds C.K. (2009) Predicting methane emissions and nitrogen excretion from cattle. J. Agric. Sci. 147:741.

[41] Eastridge M.L (2006) Major advances in applied dairy cattle nutrition. J Dairy Sci. 89:1311-1323.

[42] Yan T, Porter M.G, Mayne C.S (2009) Prediction of methane emission from beef cattle using data measured in indirect open-circuit respiration calorimeters. Animal 3:14551462.

[43] Moate P.J, Williams S.R.O, Grainger C, Hannah M.C, Ponnampalam E.N, Eckard R.J (2011) Influence of cold-pressed canola, brewers grains and hominy meal as dietary supplements suitable for reducing enteric methane emissions from lactating dairy cows. Anim. Feed Sci. Technol. 166-167: 254-264.

[44] Benchaar C, Pomar C, Chiquette J (2001) Evaluation of dietary strategies to reduce methane production in ruminants: a modelling approach. Can. J. Anim. Sci. 81:563-574.

[45] Palliser C.C, Woodward S.L (2002) Using models to predict methane reduction in pasturefed dairy cows. In: Proceedings Integrating Management and Decision Support. Part 1, 482. (Coordinated by Susan M. Cuddy) (CSIRO, Australia) pp. 162-167. (CSIRO: Canberra).

[46] Mills J.A.N, Kebreab E, Yates C.M, Crompton L.A, Cammell S.B, Dhanoa M.S, Agnew R.E, France J (2003) Alternative approaches to predicting methane emissions from dairy cows. J. Anim. Sci. 81:3141-3150.

[47] Kebreab E, France J, McBride B.W, Odongo N, Bannink A, Mills J.A.N, Dijkstra J (2006b) Evaluation of models to predict methane emissions from enteric fermentation in North American dairy cattle. In: Kebreab E, Dijkstra J, France J, Bannink A, Gerrits W.J.J (Eds.), Nutrient Digestion and Utilization in Farm Animals: Modelling Approaches. CAB International, Wallingford, UK, pp. 299 -313.

[48] Bell M.J, Wall E, Russell G, Simm G (2009) Modelling methane output from lactating and dry dairy cows. In: MacLeod M, Mayne S, McRoberts N, Oldham J, Renwick A, Rivington M, Russell G, Toma L, Topp K, Wall E, Wreford A (Eds.), Aspects of Applied Biology 93, Integrated Agricultural Systems: Methodologies, Modeling and Measuring. Association of Applied Biologists, Wellesbourne, UK, pp. 47-53.

[49] Benchaar C, Rivest J, Pomar C, Chiquette J (1998) Prediction of methane production from dairy cows using existing mechanistic models and regression equations. J. Anim. Sci. 76:617-627.

[50] Thornley J.H.M, France, J (2007) Mathematical Models in Agriculture. Second Edition. CAB International, Wallingford, UK. 
[51] Baldwin R.L, Thornley J.H.M, Beever D.E (1987) Metabolism of the lactating cow. Digestive elements of a mechanistic model. J. Dairy Res. 54:107-131.

[52] Lescoat P, Sauvant D (1995) Development of a mechanistic model for rumen digestion validated using duodenal flux of amino acids. Reprod. Nutr. Dev. 35:45-70.

[53] Pitt R.E, van Kessel J.S, Fox D.G, Pell A.N, Barry M.C, van Soest P.J (1996) Prediction of ruminal volatile fatty acids and $\mathrm{pH}$ within the net carbohydrate and protein system. J. Anim. Sci. 74:226-244.

[54] Kohn R.A, Boston R.C (2000) The role of thermodynamics in controlling rumen metabolism. In: McNamara J.P, France J, Beever D.E (Eds.), Modelling Nutrient Utilization in Farm Animals. CAB International, Wallingford, UK, pp. 11-24.

[55] Giger-Reverdin S, Morand-Fehr P, Tran G (2003) Literature survey of the influence of dietary fat composition on methane production in dairy cattle. Livest. Prod. Sci. 82:73-79.

[56] van Laar H, van Straalen W.M (2004) Ontwikkeling van een rantsoen voor melkvee dat de methaanproductie reduceert. Schothorst Feed Reseatrch, Lelystad, The Netherlands.

[57] Danfær A, Huhtanen P, Udén P, Sveinbjornsson J, Volden H (2006) The nordic dairy cow model, Karoline. In: Kebreab E, Dijkstra J, France J, Bannink A Gerrits W.J.J (Eds.), Modelling Nutrient Utilization in Farm Animals. CAB International, Wallingford, UK, pp. 383-406.

[58] Dijkstra J, Bannink A, van der Hoek K.W, Smink W (2006) Simulation of variation in methane emission in dairy cattle in The Netherlands. J. Dairy Sci. 89:259.

[59] Offner A, Sauvant D (2006) Thermodynamic modelling of ruminal fermentations. Anim. Res. 55:1-23.

[60] Moe P.W, Tyrrell H.F (1979) Methane production in dairy cows. J. Dairy Sci. 62:1583.

[61] Yan T, Agnew R.E, Gordon F.J, Porter M.G (2000) Prediction of methane energy output in dairy and beef cattle offered grass silage-based diets. Livest. Prod. Sci. 64:253-263.

[62] van Straalen W.M (2005) Voorspelling van de methaanproductie op een aantal praktijkbedrijven op basis van de rantsoensamenstelling en productieniveau. Schothorst Feed Reseatrch, Lelystad, The Netherlands.

[63] Bratzler J.W, Forbes E.B (1940) The estimation of methane production by cattle. J. Nutr. 19:611-613.

[64] Holter J.B, Young A.J (1992) Methane prediction in dry and lactating Holstein cows. J. Dairy Sci. 75:2165-2175.

[65] Johnson D.E, Ward G.M (1996) Estimates of animal methane emissions. Environ. Monit. Assess. 42:133-141.

[66] Yates C.M, Cammell S.B, France J, Beever D.E (2000) Prediction of methane emissions from dairy cows using multiple regression analysis. In: Proceedings of the British Society for Animal Science, 94.

[67] Boadi D, Wittenberg K.M (2002) Methane production from dairy and beef heifers fed forages differing in nutrient density using the sulphur hexafluoride $\left(\mathrm{SF}_{6}\right)$ tracer gas technique. Can. J. Anim. Sci. 82:201-206.

[68] Yan T, Mayne C.S, Porter M.G (2005) Effects of dietary and animal factors on methane production in dairy cows offered grass silage-based diets. In: Proceedings of the $2^{\text {nd }}$ Greenhouse Gases and Animal Agriculture Conference, Zurich, Switzerland, pp.131134. 
[69] Yan T, Mayne C.S (2007) Mitigation strategies to reduce methane emission from dairy cows. In: High Value Grassland: Providing Biodiversity, a Clean Environment and Premium Products. University of Keele, Staffordshire, UK, pp. 345-348.

[70] Reynolds C.K, Crompton L.A., Mills J.A.N (2011) Improving the efficiency of energy utilisation in cattle. Anim. Prod. Sci. 51:6-12.

[71] IPCC (Intergovernmental Panel on Climate Change) (1997) Revised 1996 IPCC Guidelines for National Greenhouse Gas Inventories: Reference Manual. Cambridge University Press, Cambridge, UK.

[72] IPCC (2006) 2006 IPCC guidelines for national greenhouse gas inventories. Eggleston, H.S., Buendia, L., Miwa, K., Ngara, T. and Tanabe, K. (Eds.), Agriculture, Forestry and other Land Use, Volume 4. Institute for Global Environmental Strategies (IGES), Hayama, Japan.

[73] Bell M.J, Wall E, Simm G, Russell G (2011) Effects of genetic line and feeding system on methane emissions from dairy systems. Anim. Feed Sci. Technol. 166-167:699-707

[74] DeRamus H.A, Clement T.C, Giampola D.D, Dickison P.C (2003) Methane emissions of beef cattle on forages: efficiency of grazing management systems. J. Environ. Qual. 32:269-277.

[75] Giger-Reverdin S, Sauvant D (2000) Methane production in sheep in relation to concentrate feed composition from bibliographic data. Cahiers Options Méditerranéennes 52:43-46.

[76] Okine E.K, Mathison G.W, Hardin R.T (1989) Effects of changes in frequency of reticular contractions on fluid and particulate passage rates in cattle. Can. J. Anim. Sci. 67:33881989.

[77] Yates C.M, Mills J.A.N, Kebreab E, Crompton L.A, France, J (2001) An integrated modelling approach to providing cost-effective means of reducing methane emissions from dairy cows. J. Agric. Sci. 137:120-121.

[78] Huque K.S, Chowdhury S.A (1997) Study on supplementing effects or feeding systems of molasses and urea on methane and microbial nitrogen production in the rumen and growth performances of bulls fed a straw diet. Asian-Austral. J. Anim. Sci. 10:35-46.

[79] Moss A (1992) Methane from ruminants in relation to global warming. Chemistry Industry 9:334-336.

[80] Lovett D.K, Lovell S, Stack L, Callan J, Finlay M, Conolly J, O’Mara F.P (2003) Effect of forage/concentrate ratio and dietary coconut oil level on methane output and performance of finishing beef heifers. Livest. Prod. Sci. 84:135-146.

[81] McGinn S.M, Beauchemin K.A, Coates T, Colombatto D (2004) Methane emissions from beef cattle: Effects of monensin, sunflower oil, enzymes, yeast and fumaric acid. J. Anim. Sci. 82:3346-3356.

[82] Beauchemin K.A, McGinn S.M (2006) Methane emissions from beef cattle: Effects of fumaric acid, essential oils, and canola oil. J. Anim. Sci. 84:1489-1496.

[83] Jordan E, Lovett D.K, Monahan F.J, Callan J, Flynn B, O'Mara F.P (2006) Effect of refined coconut oil or copra meal on methane output and performance of beef heifers. $\mathrm{J}$. Anim. Sci. 84:162-170.

[84] Dohme F, Machmüller A, Wasserfallen A, Kreuzer M (2000) Comparative efficiency of various fats rich in medium-chain fatty acids to suppress ruminal methanogenesis as measured with RUSITEC. Can. J. Anim. Sci. 80:473-782. 
[85] Chaudhry A.S, Khan M.M.H (2010) Effect of various spices on in vitro degradability, methane and fermentation profiles of different ruminant feeds. In: Proceedings of the 4th Greenhouse Gases and Animal Agriculture Conference, 3-8 October, Banff, Canada.

[86] Mohammed N, Onodera R, Itabashi H, Ara Lila Z (2004) Effects of ionophores, vitamin B6 and distiller's grains on in vitro tryptophan biosynthesis from indolepyruvic acid, and production of other related compounds by ruminal bacteria and protozoa. Anim. Feed Sci. Technol. 116:301-311.

[87] Boadi D.A, Wittenberg K.M, Scott S.L, Burton D, Buckley K, Small J.A, Ominski K.H (2004) Effect of low and high forage diet on enteric and manure pack greenhouse gas emissions from a feedlot. Can. J. Anim. Sci. 84:445-453.

[88] Odongo N.E, Bagg R, Vessie G, Dick P, Or-Rashid M.M, Hook S.E, Gray J.T, Kebreab E, France J, McBride B.W (2007) Long-term effects of feeding monensin on methane production in lactating dairy cows. J. Dairy Sci. 90:1781-1788.

[89] Johnson K.A, Huyler M.T, Westberg H.H, Lamb B.K, Zimmerman P (1994a.) Measurement of methane emissions from ruminant livestock using a $\mathrm{SF}_{6}$ tracer technique. Environ. Sci. Technol. 28:359-362.

[90] Johnson D.E, Abo-Omar J.S, Saa C.F, Carmean B.R (1994b) Persistence of methane suppression by propionate enhancers in cattle diets. In: Aquilera, J.F. (Ed.), Energy Metabolism of Farm Animals. EAAP Publication No. 76. CSIC Publishing Service, Granada, Spain, pp. 339-342.

[91] Sauer F.D, Fellner V, Kinsman R, Kramer J.K.G, Jackson H.A, Lee A.J, Chen S (1998) Methane output and lactation response in Holstein cattle with monensin or unsaturated fat added to the diet. J. Anim. Sci. 76:906-914.

[92] McGuffey R.K, Richardson L.F, Wilkinson J.I.D (2001) Ionophores for dairy cattle: current status and future outlook. J Dairy Sci. 84:194-203.

[93] Grainger C, Auldist M.J, Clarke T, Beauchemin K.A, McGinn S.M, Hannah M.C, Eckard R.J, Lowe L.B (2008) Use of Monensin Controlled-Release Capsules to Reduce Methane Emissions and Improve Milk Production of Dairy Cows Offered Pasture Supplemented with Grain. J. Dairy Sci. 91:1159-1165.

[94] Grainger C, Williams R, Eckard R.J, Hannah M.C (2010) A high dose of monensin does not reduce methane emissions of dairy cows offered pasture supplemented with grain. J. Dairy Sci. 93:5300-5308.

[95] Grainger C, Clarke T, Auldist M.J, Beauchemin K.A, McGinn S.M, Waghorn G.C, Eckard R.J (2009). Potential use of Acacia mearnsii condensed tannins to reduce methane emissions and nitrogen excretion from grazing dairy cows. Can. J. Anim. Sci. 89:241-251.

[96] Animut G, Puchala R, Goetsch A.L, Patra A.K, Sahlu T, Varel V.H, Wells J (2007) Methane emission by goats consuming diets with different levels of condensed tannins from lespedeza. Anim. Feed Sci. Technol. 144:212-227.

[97] McAllister T.A, Newbold C.J (2008) Redirecting rumen fermentation to reduce methanogenesis. Aust. J. Exp. Agric. 48:7-13.

[98] Beauchemin K.A, Kreuzer M, O'Mara F, McAllister T.A (2008) Nutritional management for enteric methane abatement: a review. Aust. J. Exp. Agric. 48:21-27. 